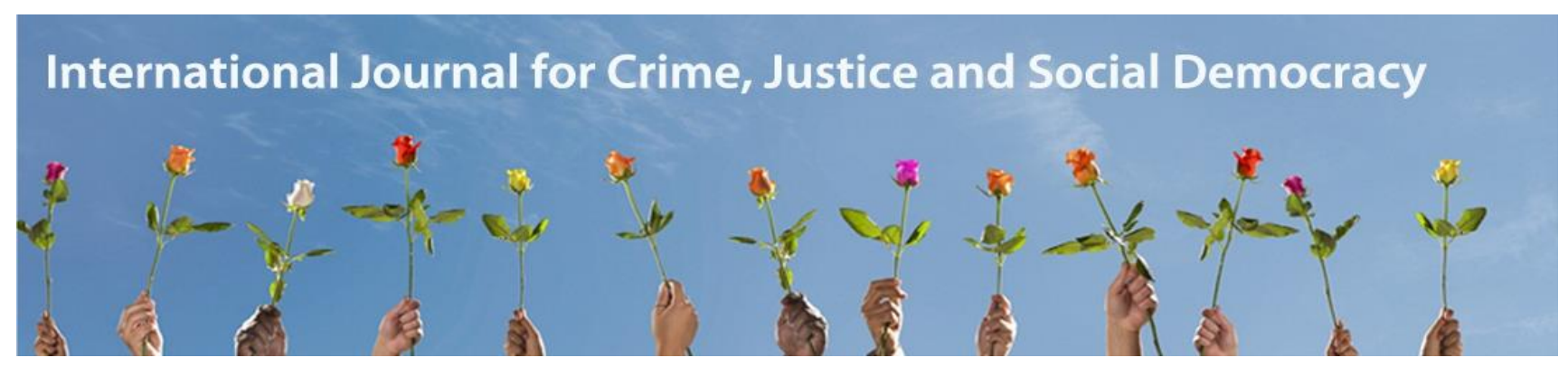

Guest Editorial

\title{
Policing and Preventing Gender Violence in the Global South
}

\section{Camilla de Magalhães Gomes}

Universidade Federal do Rio de Janeiro, Brazil

\section{Carmen Hein de Campos}

Centro Universitário Ritter dos Reis, Brazil

Melissa Bull

Queensland University of Technology, Australia

Kerry Carrington,

Queensland University of Technology, Australia

\section{Introduction}

This special issue Policing and Preventing Gender Violence in the Global South, is the product of a workshop on innovations in policing and preventing gender violence in the Global South, hosted by Queensland University of Technology (QUT) Centre for Justice, 3-4 December 2019. The event was attended by scholars from Brazil, Pacific Island communities, Bangladesh, Argentina, and several Australian jurisdictions. Hence the articles in this special issue reflect the diverse nationalities present at the event. A central aim of the workshop realised in this special issue is the stimulation of innovation in understanding the policing and prevention of gender violence through novel international collaborations and cross-fertilisation. It reverses the assumptions that underpin the epistemic injustice of the social sciences, that innovations generally flow only from the Global North to the Global South. This special issue shows that it can be the other way round.

This special issue compliments the special issue on the Criminalisation and the Violence(s) of the State: Criminalising Men, Punishing Women edited by Sandra Walklate and Kate Fitz-Gibbon, that debates the problems arising from the tendency in feminism to call for more law and more criminalisation as a way of addressing men's violence. As the contributors to that issue emphasise these approaches, heavily influenced by American feminism of the 1970s, have had unintended consequences leading to the punishment of women, the misidentification of perpetrators and the massive increases in the criminalisation of women and men of colour. 
Much of the current knowledge about the policing and prevention of gender violence has been heavily influenced by thinking and empirical research in the Global North, where the resources for undertaking research are concentrated. These knowledges tend to be universalised as timeless and placeless. Agendas of decolonisation and southernising perspectives which frame many of the contributions to this special issue, challenge this universalist way of thinking, problematise and resist relations of hierarchy, dependency and subordination between the Global North and South in the production of knowledge.

The project links closely to other movements such as border thinking, epistemologies of the south, critical criminology, southern feminist theory, ideas of epistemic injustice and the work of counter-colonial, postcolonial and de-colonial scholars. This selection of articles seeks to be more inclusive of multiple subaltern and peripheral voices including Indigenous, migrant, coloured and gendered voices, that seek to recover both historical legacies of the violence of colonisation in addition to the legacies of coloniality on gender violence in the present. By bringing a diverse array of scholars together from across the Global South we hope to stimulate further debate about the contributions that can be made from scholars from the Global South to innovating the policing and prevention of gender violence.

Please cite this Guest Editorial as:

Magalhães Gomes C, Campos CH, Bull M and Carrington K (2021) Special issue. Policing and preventing gender violence in the Global South. Guest editorial. International Journal for Crime, Justice and Social Democracy 10(4): i-ii. https://doi.org/10.5204/ijcjsd.2186

Except where otherwise noted, content in this journal is licensed under a Creative Commons Attribution 4.0 International Licence. As an open access journal, articles are free to use with proper attribution.

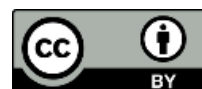

